\title{
Sistem Boarding School Dalam Membentuk Kemandirian Siswa Madrasah Aliyah Negeri 1 Kota Pekalongan
}

\author{
Muhammad Khoiruzzadi*, Muhammad Luqmanul Hakim \\ Universitas Islam Negeri (UIN) Sunan Kalijaga Yogyakarta, Indonesia, Institut Agama \\ Islam Negeri (IAIN) Pekalongan, Indonesia \\ Jl. Laksda Adisucipto, Papringan, Caturtunggal, Kec. Depok, Kabupaten Sleman, Daerah \\ Istimewa Yogyakarta 55281, Jl. Kusuma Bangsa No.9, Panjang Baru, \\ Pekalongan Utara, Kota Pekalongan, Jawa Tengah 51141 \\ Email: khoiruzzadie@gmail.com
}

\begin{abstract}
This study aims to determine the activities that exist in the boarding school system, and forms of student independence at boarding school in MAN 1 Pekalongan City. This research is included in the field research with a descriptive qualitative approach. Data obtained from interviews with the head of the boarding house, carers of male dormitory and 3 boarding school students, and observations related to teacher learning and student independence. Analysis of the data used according to Miles and Huberman, namely: data reduction, data presentation, and drawing conclusions. The results of this study that boarding school aims to form students who are independent, both emotionally, economically, intellectually, and socially. Forms of independence of students at boarding school such as washing clothes, washing cooking utensils, cleaning the bed as well as his room. Student independence is formed because of the habituation of all activities in boarding school and repetitions as reinforcement of the independent attitude that students already have. So it is hoped that there will be special research on students' selfawareness while at boarding school MAN 1 Pekalongan City.
\end{abstract}

Keywords: Boarding School, Student, Independent

Abstrak: Penelitian ini bertujuan untuk mengetahui kegiatan yang ada dalam sistem boarding school, dan bentuk kemandirian siswa di boarding school di MAN 1 Kota Pekalongan. Penelitian ini termasuk dalam penelitian lapangan dengan pendekatan kualitatif deskriptif. Data didapat dari hasil wawancara dengan kepala asrama, pengasuh asrama putra dan 3 siswa boarding school, dan hasil observasi terkait pembelajaran guru dan kemandirian siswa. Analisis data yang digunakakan menurut Miles dan Huberman, yaitu: reduksi data, penyajian data, dan penarikan kesimpulan. Hasil dari penelitian ini bahwa boarding school bertujuan membentuk siswa yang mandiri, baik secara emosional, ekonomi, intelektual, dan sosial. Bentuk kemandirian siswa di boarding school seperti mencuci pakaian, mencuci peralatan masak, membersihkan tempat tidur sekaligus kamarnya. Kemandirian siswa dibentuk karena pembiasaan dari seluruh kegiatan yang ada di boarding school dan pengulanganpengulangan sebagai penguat dari sikap mandiri yang sudah dimiliki siswa. Sehingga diharapkan, ada penelitian khusus kesadaran diri siswa selama di boarding school MAN 1 Kota Pekalongan.

Kata Kunci: Boarding School, Siswa, Kemandirian

Jurnal Pendidikan Agama Islam Al-Thariqah Vol. 5, No. 2, Juli - Desember 2020

Received: 19 February 2020; Accepted 09 May 2020; Published 15 August 2020

*Corresponding Author: khoiruzzadie@gmail.com 


\section{PENDAHULUAN}

Pada tahun 2019, Indeks pembangunan manusia (IPM) Indonesia berada di angka 71,92. Angka ini meningkat sebesar 0,74 persen dibandingkan tahun 2018 (Badan Pusat Statistik, 2020). Selain itu, Indeks pembangunan manusia (IPM) ditentukan oleh tiga hal, yaitu kemampuan daya beli masyarakat, kesehatan masyarakat, dan pendidikan yang dimiliki masyarakat (Sadulloh, 2010, h. 73). Di sisi lain, tantangan global yang semakin berkembang menuntut masyarakat tidak ketertinggalan dengan kemajuan tapi tetap bisa menjaga jati diri bangsa Indonesia yang beradab. Jadi tidak salah, pendidikan merupakan salah satu faktor penentu dalam keberhasilan suatu masyarakat. Untuk membentuk manusia yang berwawasan luas tentang Islam, ada lembaga formal, non formal dan informal yang berfokus pada konsep keislaman seperti pondok pesantren dan madrasah (Susiyani \& Subiyantoro, 2017, h. 327). Pondok pesantren dan madrasah berperan dalam menghasilkan siswasiswi yang berkarakter sesuai dengan nilai-nilai Islami (Das, Halik, \& Amaluddin, 2016, h. 24).

Madrasah Aliyah Negeri (MAN) 1 Kota Pekalongan merupakan lembaga pendidikan yang mencetak generasigenerasi penerus bangsa yang berkompeten. Hal ini ditandai dengan belajar ilmu pengetahuan dan ilmu agama didukung dengan keterampilan untuk bekal peserta didik di kehidupan masa yang akan datang. Selain itu, di Madrasah Aliyah Negeri (MAN) 1 Kota Pekalongan juga menerapkan boarding school bagi siswa-siswinya yang berminat untuk tinggal di boarding school.

Boarding school merupakan sekolah untuk para siswa agar tidak pulang pergi, tetapi menginap di asrama sekolah selama masa proses pendidikan. Keberadaannya juga mendapatkan dari dukungan dari siswa itu sendiri dan juga dari orang tua siswa (Martin, Papworth, Ginns, \& Liem, 2014, h. 1007). Sistem boarding school mengadopsi dari pendidikan pesantren yang dibungkus dengan istilah sekolah unggulan dan sudah ada sejak lama, untuk itu boarding school telah mengadopsi pendidikan pesantren secara diam-diam (Haeruddin, Rama, \& Naro, 2019, h. 60; Qomar, 2008, h. 82).

Di boarding school mempunyai tugas yang penting khususnya dalam membentuk karakter, mengembangkan kepribadian, dan menanamkan nilai-nilai hidup jika dibanding dengan sekolah yang tidak memiliki konsep boarding school (Fathonah, Hernawaty, \& Fitria, 2017, h. 69). Melalui boarding school, banyak manfaat yang bisa diraih, antara lain jadwal belajar lebih teratur (Behaghel, de Chaisemartin, \& Gurgand, 2017, h. 140), kesehatan mental yang baik (EvansCampbell, Walters, Pearson, \& Campbell, 2012, h. 421; Yin dkk., 2017, h. 59), asupan jadwal makan yang teratur sehingga asupan gizi tercukupi (Sutyawan \& Setiawan, 2013, h. 207), pembugaran kondisi fisik (Susanto, Sulistyorini, Wuryaningsih, \& Bahtiar, 2016, h. 291), melatih sikap kemandirian pada diri santri (Qomar, 2015, h. 136) dan lainnya. Akan tetapi ada beberapa hal yang perlu diperhatikan juga hal-hal yang sulit dikembangkan anak selama di boarding school, seperti proses adaptasi yang lama jika anak selama bersama orang tuanya selalu dimanja, kurang nafsu makan dengan masakan yang ada di boarding school (Mander, Leaster, \& Cross, 2015, h. 140), dan jika berlarut anak akan menjadi depresi dan tidak nyaman selama di boarding school (Schaverien, 2011, h. 141).

Dari manfaat yang nantinya akan dirasakan oleh siswa, namun ada hal yang perlu digarisbawahi ketika siswa yang baru belum nyaman selama di boarding school sehingga memutuskan untuk keluar dan hanya berfokus untuk sekolah 
reguler saja. Para siswa agar cepat beradaptasi selama di boarding school, mereka dituntut mengikuti aturan yang ada dan berusaha meninggalkan kebiasaan yang tidak baik selama tinggal di rumah dengan orang tuanya (Schaverien, 2011, h. 138). Jika siswa sudah mampu beradaptasi, kemungkinan untuk depresi, cemas, emosi, dan stress bisa lebih ditekan oleh siswa (Mander dkk., 2015, h. 131).

Hal yang terpenting selama di boarding school, siswa-siswi harus mampu mandiri agar tetap nyaman dan bagus untuk masa depan siswa (Keller \& Brown, 2014, h. 428). Selain itu, siswa haruslah disiplin terhadap waktu, menghadapi masalah sendiri dan tidak bergantung kepada orang lain (Behaghel dkk., 2017, h. 140). Perbuatan siswa yang serba mandiri diharapkan mampu membuat siswa cenderung percaya diri dan berani dalam menjalani kehidupan. Dari kemandirian tersebut dapat membuat siswa membendung dan menyaring segala bentuk hal yang bisa menyebabkan siswa berperilaku menyimpang dari norma agama (EvansCampbell dkk., 2012, h. 422; Fathonah dkk., 2017, h. 73).

Kehadiran boarding school di MAN 1 Kota Pekolangan ini menjawab problematika dari masyarakat karena pada zaman sekarang siswa tidak bisa menerapkan perilaku yang baik ketika berada di lingkungan sosial. Seluruh siswa mempunyai kesempatan untuk mendaftarkan dirinya menjadi siswa di boarding school MAN 1 Kota Pekalongan, lebih-lebih asrama ini bisa dimanfaatkan oleh siswa yang rumahnya jauh. Kegiatan yang ada di asrama salat berjamaah, setelah salat subuh dan setelah salat isya' siswa membaca Al-Qur'an ada juga tambahan pembelajaran ilmu umum (mengulangi materi yang di ajarkan di kelas).

Dari hal tersebut di atas, penulis melakukan penelitian di MAN 1 Kota
Pekalongan terkait boarding school yang diterapkan di sana karena untuk boarding school untuk siswa laki-laki. baru diterapkan pada tahun 2019, berbeda dengan siswa putri yang sudah ada sejak tahun 2016. Sehingga penulis tertarik meneliti kegiatan di boarding school siswa laki-laki yang masih baru diterapkan di MAN 1 Kota Pekalongan. Aspek yang terpenting dalam kesiapan siswa selama berada di boarding school adalah aspek kemandirian, apalagi tergolong masih baru dalam pengelolaan boarding school siswa laki-laki dan perlu adaptasi. Adapun tujuan penelitian ini adalah untuk mengetahui kegiatan yang ada dalam sistem boarding school di MAN 1 Kota Pekalongan, dan bentuk kemandirian siswa selama di boarding school di MAN 1 Kota Pekalongan.

\section{KONSEP TEORI}

Boarding school merupakan sebuah sistem yang meniru gaya pondok pesantren. Di Indonesia khususnya pulau Jawa, lebih mirip dengan pemondokan dalam lingkungan padepokan, yaitu perumahan sederhana yang di petakpetak dalam bentuk kamar-kamar yang merupakan asrama bagi santri kamar yang merupakan asrama bagi santri (Nasir, 2011, h. 80). Di boarding school juga memperhatikan aspek dan nilai yang ada di masyarakat sebagai pengembangan yang akan dibentuk pada diri siswa. Dari awal mula berdirinya boarding school sangat berpatokan dan penekanan pada nilai-nilai moralitas, menjunjung nilai kemandirian, kebersamaan, dan kesederhanaan (A'la, 2006, h. 49).

Kemandirian termasuk dalam kunci keberhasilan yang harus dimiliki individu. Kemandirian merupakan kemampuan yang dimiliki individu yang dibentuk melalui pengalaman dalam hidupnya melalui proses pembelajaran agar tidak bergantung pada orang lain, memiliki sikap percaya diri, bisa mengambil 
keputusan yang tepat, dan berani bertanggung jawab terhadap sesuatu yang dikerjakannya (Desmita, 2010, h. 185). Seseorang yang memiliki sikap mandiri tidak memerlukan petunjuk yang rumit dan secara berkesinambungan dalam mencapai tujuan akhir, dan ia mampu melakukannya secara sendiri. Namun dalam realitasnya, terlihat siswa dalam asrama banyak yang pulang ke rumah. Disebabkan siswa asrama yang pulang itu karena jarak antara sekolah dan rumah tidak terlalu jauh. Robert Havinghurst membagi kemandirian manusia baik secara emosi, intelektual, ekonomi, dan sosial (Desmita, 2010, h. 186).

\section{METODE PENELITIAN}

Penelitian ini termasuk dalam penelitian lapangan (field research). Pendekatan yang dipakai adalah dengan pendekatan kualitatif deskriptif, yaitu prosedur dalam penelitian yang menggunakan kata-kata tertulis dari data yang didapat di lapangan kemudian dijabarkan secara deskriptif. Untuk data primer adalah data yang diperoleh dari hasil wawancara dengan kepala asrama, pengasuh asrama putra dan 3 siswa boarding school, kemudian hasil observasi terkait pembelajaran guru dan kemandirian siswa boarding school MAN 1 Kota Pekalongan. Dalam pemilihan 3 siswa berdasarkan tempat tinggal siswa yang berbeda, sehingga diharapkan mampu merepresentasikan siswa yang ada di boarding school yang berasal dari Batang, Pemalang, dan Tegal. Sedangkan data sekunder diperoleh dari dokumentasi seperti dokumen kepengurusan boarding school, program unggulan, visi dan misi, dan lainnya.

Dari data yang sudah didapat kemudian dikumpulkan dan dipilah sesuai dengan kebutuhan dalam menjawab hasil dari penelitian. Dari data yang sudah dipilah dan dipelajari secara berkala, selanjutnya adalah menganalisisnya, dengan cara mengkaji dan menelaah lebih lanjut terkait data yang sudah didapatkan kemudian dikaitkan dengan teori yang sudah mapan. Adapun proses analisisnya adalah dengan tiga tahapan yaitu reduksi data, menyajikan data, dan penarikan kesimpulan (Afifudin, 2012, h. 165). Teknik dalam menguji keabsahan data dengan menggunakan triangulasi sebagai pengecekan data dari berbagai sumber dengan berbagai cara, dan berbagai waktu.

Berikut dipaparkan tabel karakter informan yang terlibat dalam penelitian.

Tabel 1. Karakteristik Informan

\begin{tabular}{lllc}
\hline No & Informan & Pekerjaan & Asal \\
\hline 1 & AM & $\begin{array}{l}\text { Kepala } \\
\text { asrama }\end{array}$ & Pekalongan \\
\hline 2 & AZ & $\begin{array}{l}\text { Pengasuh } \\
\text { asrama } \\
\text { putra }\end{array}$ & Pekalongan \\
& & $\begin{array}{l}\text { Siswa } \\
\text { kelas 10 }\end{array}$ & Tegal \\
\hline 3 & EF & Siswa & Pemalang \\
& & kelas 10 & \\
\hline 4 & MHM & $\begin{array}{l}\text { Siswa } \\
\text { kelas 10 }\end{array}$ & Batang \\
\hline 5 & ZA & & \\
\hline
\end{tabular}

\section{HASIL DAN PEMBAHASAN \\ Hasil Penelitian \\ Sistem Boarding School MAN 1 Kota Pekalongan}

Boarding school di MAN 1 Kota

Pekalongan memiliki struktur organisasi, dari yang paling tertinggi yaitu kepala asrama, sekretaris dan pengasuh asrama. Pengasuh asrama bertugas memberikan bimbingan dan melatih kepada seluruh siswa asrama, mengontrol perkembangan kepribadian dan sikap belajar siswa, menerapkan disiplin disegala aspek di asrama, memberikan pembinaan dan pembinaan keterampilan (skill) yang bersifat keagamaan dan manajemen diri sesuai dengan program-program pembiasaan yang diterapkan, mengayomi seluruh siswa untuk mewujudkan ketenangan asrama, bertindak tegas 
terhadap pelanggaran tata tertib, membuat laporan secara berkala kepada kepala asrama. Segala keadministrasian dan keuangan dikelola oleh sekretaris dan bendahara asrama. Kepala asrama bertanggung jawab dan melaporkan segala urusan asrama kepada kepala madrasah.

MAN 1 Kota Pekalongan memiliki asrama untuk putra dan putri. Untuk asrama putri dapat dikatakan lebih bagus dari pada asrama putra apabila dilihat dari fasilitasnya, ini disebabkan karena boarding school yang sudah diterapkan terlebih dahulu itu untuk siswi putri dan sudah mempunyai 3 angkatan beda dengan asrama putra yang masih mempunyai 1 angkatan (dimulai dari pendaftaran sekolah angkatan 2019). Tentunya gedung-gedung untuk asrama putri sudah lengkap lain halnya dengan asrama putra yang belum memiliki aula dan kamar tidur masih menggunakan bangunan dari peninggalan kantor urusan agama (KUA). Aula putri sebagai pusat kegiatan pembelajaran untuk siswi mereka belajar kitab kuning, belajar bahasa, hafalan dan untuk sholat berjamaah. Berbeda dengan asrama putra seluruh kegiatan pembelajaran dipusatkan di masjid. Pembelajaran dengan sistem boarding school ini meliputi kajian kitab-kitab klasik, baca tulis Al-Qur'an dan berlatih bahasa asing yakni bahasa Arab dan bahasa Inggris. AM selaku kepala asrama mempunyai sebuah target untuk siswa laki-laki maupun perempuan yang mengikuti boarding school target tersebut yaitu hafal 1 juz dalam satu semester. Maka dari itu pengasuh dari masing-masing asrama ialah lulusan dari pondok pesantren yang sekaligus seorang hafidz dan hafidzoh.

Untuk memenuhi kebutuhan fasilitas sarana dan prasarana untuk kegiatan belajar mengajar maka siswa yang ikut program boarding school di minta pembayaran uang gedung asrama sebesar Rp. 500.000 selama satu semeseter. Fasilitas yang didapat berupa kasur tempat tidur, lemari pakaian dan makan. Dengan mengikuti program boarding school, siswa jadi lebih hemat untuk pengeluaran pulang pergi sekolah, karena gedung asrama masih satu lingkungan dengan MAN 1 Kota Pekalongan.

Menurut AM selaku kepala asrama "Kebanyakan siswa yang mengikuti program boarding school ini kebanyakan domisilinya jauh-jauh, jadi asrama ini bisa dimanfaatkan oleh siswa yang rumahnya jauh dengan begitu orang tua dapat memangkas uang transportasi dan anak pun terlatih mengatur keuangannya sendiri". Hal inilah yang menjadikan sumber latihan siswa untuk hidup mandiri.

Lebih dari itu, siswa yang mengikuti boarding school dituntut untuk bisa mandiri dalam kesehariannya, karena mereka terlepas dari ketergantungan dengan keluarga atau orang tua murid. Siswa yang mengikuti boarding school dilatih untuk mandiri dalam hal disiplin waktu, hal ini digambarkan dengan situasi jadwal kegiatan sholat berjamaah lima waktu hukumnya wajib apabila terjadi pelanggaran maka denda dengan nominal uang Rp. 10.000. sebagaimana penuturan dari salah satu siswa (MHM), dia menjelaskan bahwa "Pak AZ selalu memantau siswa di asrama, apalagi yang berhubungan dengan sholat. Pak AZ selaku pengasuh asrama benar-benar memantau siswanya supaya bisa melakukan sholat wajib tepat waktu dan dilaksanakan secara berjamaah. Terlihat sering kali saya terbangun ketika pukul 03.00 WIB. ketua asrama bersama pengasuh membangun siswa asrama untuk melakukan solat malam kemudian dilanjutkan dengan sholat subuh berjamaah".

Siswa boarding school juga bertanggung jawab atas kebersihan asrama baik itu dari kamar tidur, ruang makan, aula dan kamar mandi. Siswa pun 
diharuskan untuk mencuci pakaiannya sendiri. Hal ini perlu pembiasaan agar siswa dapat menyelesaikan tugas pribadi. Salah satu pembelajaran di asrama ada muhadharah, ilmu dari muhadharah diharapkan dapat melatih mental siswa ketika berbicara didepan umum atau orang banyak. Seperti yang dikatakan AZ, beliau mengatakan bahwa "Di asrama ini juga kami membekali siswa untuk belajar khitobah atau muhadharah, ini berfungsi supaya melatih mental para siswa ketika berbicara didepan banyak orang, karena setelah lulus para siswa akan kembali lagi ke lingkungan sosial yang lebih luas".

Siswa yang ikut boarding school sering belajar bersama-sama, jika ada PR atau tugas dari gurunya maka siswa akan mengerjakannya secara berkelompok. Biasanya siswa yang pandai menjadi pengarah bagi teman-temannya yang kurang paham dengan tugasnya. Siswa yang mengikuti boarding school waktunya lebih bermanfaat dari pada siswa yang tidak ikut boarding school karena mereka setelah pulang sekolah waktu luang digunakan untuk bermain. Lain halnya dengan siswa yang ikut program boarding school waktu luang mereka bisa dimanfaatkan untuk belajar dari sore sekitar pukul 16.00 belajar kajian kitab klasik, kemudian dilanjutkan tahsinul qur'an dan belajar bahasa kemudian belajar mandiri atau kelompok sampai pukul 22.00 .

Hal ini selaras apa yang disampaikan oleh salah satu siswa (EF), dia menjelaskan bahwa "Pengasuh asrama selalu memantau saya dan temanteman, lebih-lebih ketika selesai pembelajaran sekolah kami dari sore sampai pagi selalu didampingi oleh pengasuh asrama dalam setiap kegiatannya. Contoh kecil saja, selain waktu salat wajib, dalam hal belajar kelompok pengasuh asrama ikut memantaunya. Jadi belajar kelompok jadi lebih kondusif tidak ada yang bercanda, terkadang pengasuh juga ikut memberikan pembelajaran ketika kami menemukan sebuah kesulitan dalam belajar. Lebih-lebih di asrama temanteman saya pada pintar jadi lebih enak jika belajar bersama dengan orang yang memiliki kepandaian diatas saya. Karena apabila belajar bersama guru saya masih mempunyai rasa malu untuk bertanya ketika tidak paham pada suatu materi akan tetapi apabila belajar bersama teman sendiri bisa bertanya lebih mendalam dan tidak ada rasa malu ataupun takut".

Boarding school juga bisa mencakup siswa dengan latar belakang yang berbeda, baik dari intelektual, kemampuan sosial, sosial budaya, bahasa, dan yang lainnya. Siswa akan menerima pembelajaran yang sama dan tidak membedakan siswa satu dengan yang lainnya. Baik dari kegiatan pembelajaran, maupun lainnya seperti makan, jam istirahat, fasilitas. Mereka lakukan secara bersama-sama sesuai dengan program yang sudah ada di dalamnya. Siswa juga akan dibentuk sikap sosialnya. Ketika ada siswa yang kesulitan, maka empati dari teman yang lainnya akan sedikit demi sedikit terbentuk dalam membantunya. Selain itu, karakter kepemimpinan juga akan terbentuk dengan sendirinya ketika siswa sudah mampu memimpin dan mengendalikan diri dengan baik.

Siswa yang hidup dalam lingkungan boarding school dapat melatih untuk bersikap menerima perbedaan jika ditemukan beberapa perbedaan dalam berpendapat ketika belajar maupun dalam menyelesaikan masalah. Seperti dikatakan oleh ZA, bahwa "Kami jadi banyak temanyang berasal dari berbagai daerah, ada yang dari Tegal, Pemalang, Brebes dan Batang. Terdapat banyak perbedaan diantara kami, dengan perbedaan itu kami bisa lebih asik dalam belajar apalagi dengan guru pengasuh yang berasal dari kota Pekalongan yang selalu mendampingi kami sebagai siswa asrama, interaksi yang kami lakukan 
tidak hanya dengan teman sejawat akan tetapi dengan pengasuh asrama dan juga karyawan asrama pun kami selalu bersendau gurau".

\section{Program Keunggulan dan Jadwal Kegiatan Boarding School Siswa Putra}

MAN 1 Kota Pekalongan dalam menjalankan boarding school mempunyai beberapa program unggulan, diantaranya program tahfidz, program bahasa (Arab dan Inggris), dan program kajian kitab klasik.

Dalam menjalankan sistem boarding school ini terdapat beberapa program baik itu kegiatan sehari-hari, mingguan maupun bulanan. Seperti yang dikatakan oleh AZ "Disini kami mempunyai kegiatan baik itu harian, mingguan maupun bulanan, kegiatan harian seperti sholat berjamaah di masjid, tadarus Al-Qur'an, dan belajar kajian kitab klasik kalau kegiatan mingguan seperti berzanji, terkadang kalau malam jumat membaca yasin dan tahlil yang di pimpin langsung oleh pengasuh asrama. Kegiatan bulanannya seperti muhadharah".

Jadwal kegiatan boarding school

MAN 1 Kota Pekalongan ini berlaku untuk semua siswa yang mengikuti boarding school tanpa terkecuali. Apabila siswa tidak mematuhi jadwal yang sudah ditentukan tersebut, maka siswa akan mendapatkan poin serta sanksi atas pelanggarannya karena sudah tidak mematuhi tata tertib yang telah ditetapkan oleh pihak madrasah.

\section{Kemandirian Siswa Boarding School}

Kemandirian siswa akan didapat melalui proses belajar dimana setiap siswa dapat mengambil inisiatif, dengan atau tanpa bantuan orang lain dalam hal menyelesaikan segala permasalahanpermasalahan yang ditimbulkan dari lingkungan. Kemandirian siswa MAN 1 Kota Pekalongan yang dibentuk melalui kegiatan sistem boarding school antara lain meliputi siswa dituntut untuk merapikan tempat tidur, membersihkan kamar, mencuci pakaian, mencuci peralatan masak. Penuturan lebih lengkap dijelaskan oleh MHM, bahwa "Di asrama itu harus terbiasa apa-apa meyelesaikan urusan pribadi walaupun terkadang muncul rasa malas namun kalau malas itu dibiarkan maka akan menumpuklah urusan pribadi kita seperti mencuci pakaian, mencuci peralatan masak, membersihkan tempat tidur sekaligus kamarnya. Kalau urusan pribadi sudah dikerjakan dan tidak menumpuk kan jadi enak kalau mau melanjutkan belajar dan mengerjakan tugas. Berbeda jika berada dirumah semua urusan pribadi dikerjakan oleh ibu saya".

Sebagai hamba Allah SWT. maka siswa diwajibkan menjalankan perintah Tuhan seperti salat fardhu. Salat fardhu ini selalu dilaksanakan secara berjamaah antara siswa dengan pengasuh asrama. Dalam hal ini bertujuan untuk siswa agar lebih disiplin terhadap waktu dan dapat menghargai waktu contohnya dengan salat fardhu tepat waktu dalam artian tidak boleh menunda waktu salat. Siswa pun diajarkan untuk bangun malam lalu salat tahajud. Sebagaimana penjelasan dari AZ, beliau menerangkan bahwa "Siswa kami dituntut dapat disiplin waktu dan dapat menghargainya, semisal ketika waktu salat tiba maka segera melaksanakan salat dengan berjamaah, salah satu siswa menjadi muadzin di masjid madrasah. Siswa tidak boleh menunda waktu salat kalau terbukti melanggar maka akan ditakzir sesuai kesepakatan, khusus untuk pelanggar salat subuh akan didenda senilai Rp. 10.000. Ini bertujuan supaya siswa terlatih tepat waktu. Di asrama ini juga siswa disuruh untuk bangun malam untuk salat tahajud".

Dalam kegiatan boarding school siswa lebih mendalami ilmu agama karena siswa dibekali ilmu agama seperti kajian kitab klasik dan terdapat pembelajaran tahsinul Qur'an. Siswa yang ikut boarding school tentunya dapat memberikan dampak positif bagi mereka 
salah satunya siswa membaca Al-Qur'an menjadi lebih baik dari pada sebelumnya. Dengan boarding school, kepala asrama memberikan target supaya siswa dapat menghafalkan Al-Qur'an setidaknya minimal 1 juz dalam satu semester. Seperti yang dikatakan oleh ZA "Saya ikut boarding school salah satu motivasinya ingin menghafalkan Al-Qur'an 1 juz dalam satu semeseter dan melantunkan suaranya dengan baik sesuai tajwid".

Proses kemandirian melalui program boarding school dilakukan secara berulang-ulang yang akan menjadikan suatu kebiasaan (Siregar \& Nara, 2011, h. 35) seperti kegiatan rutin salat berjamaah, dan memelihara kebersihan diri, memberi salam, membuang sampah pada tempatnya, melakukan kebiasaan antri, berpakaian rapi, berbahasa yang baik, menghormati orang yang lebih tua dan menyayangi yang muda. Kegiatan dilakukan atas dasar inisiatif sendiri, tanggung jawab, serta disiplin. Dari pembiasaan tersebut dengan sendirinya akan muncul kemandirian pada siswa.

\section{Pembahasan Penelitian}

\section{Boarding School Dalam Membentuk Kemandirian}

Boarding School merupakan sebuah sistem yang meniru gaya pondok pesantren. Di Indonesia khususnya pulau Jawa, lebih mirip dengan pemondokan dalam lingkungan padepokan, yaitu perumahan sederhana yang di petakpetak dalam bentuk kamar-kamar yang merupakan asrama bagi santri kamar yang merupakan asrama bagi santri (Nasir, 2011, h. 80). Konsep sekolah dengan sistem boarding school ini hampir sama dengan lembaga pendidikan yang memadukan dengan pesantren, letak perbedaannya hanya pada istilah penamaan dan lingkungan saja. Misalnya, dalam pesantren terdapat kyai, sedangkan di boarding school seorang kyai diganti dengan pembimbing (Busyairi AS, 2017, h. 56).

Kemudian, di pesantren terdapat masjid, sedangkan di boarding school sebuah masjid diganti dengan aula atau gedung serba guna. Akan tetapi tujuannya sama yaitu membentuk manusia yang cerdas intelektual, cerdas spiritual dan cerdas emosional (Rajab, 2014, h. 257; Sawaluddin, 2018, h. 40; Tafsir, 2004, h. 212). Sistem pendidikan seperti ini dapat memberikan pengawasan terhadap siswa dalam melakukan kegiatannya, dengan adanya pengawasan prestasi siswa dengan ilmu pengetahuan. Pendidikan ini dilakukan di asrama, berlangsung selama 24 jam setiap hari, dengan jadwal yang terprogram secara konkrit dan jelas. Jadwal yang ketat dan terstruktur yang diselenggarakan lembaga selama 24 jam setiap hari, dapat di pahami bahwa pendidikan dengan sistem boarding school dilakukan dengan manajemen waktu sistematis dan memadai (Usman \& Marzuki, 2016, h. 205).

Di boarding school juga memperhatikan aspek dan nilai yang ada di masyarakat sebagai pengembangan yang akan dibentuk pada diri siswa. Dari awal mula berdirinya boarding school sangat berpatokan dan penekanan pada nilai-nilai moralitas, menjunjung nilai kemandirian, kebersamaan, dan kesederhanaan (A'la, 2006, h. 49). Dengan adanya boarding school, siswa sangat dituntut untuk mandiri mengurus dirinya baik mencuci pakaian, piring, kebersihan asrama baik itu dari kamar tidur, ruang makan, aula dan kamar mandi. Di boarding school MAN 1 Kota Pekalongan untuk makan siswa ada petugas yang memasakkan untuk para siswa yang menempati boarding school.

Dengan jadwal, rutinitas dan program unggulan dari boarding school MAN 1 Kota Pekalongan, setidaknya membuat siswa harus terbiasa dan segera beradaptasi dengan jadwal dan aktivitas yang menjadi keseharian anak di 
boarding school. Adapun manfaat dari boarding school adalah sebagai berikut:

Pertama, Belajar mandiri, hidup mandiri bukan berarti segala sesuatu dilakukan secara individual, karena berada di asrama maka perlu adanya adaptasi dengan teman lainnya. Siswa boarding school MAN 1 Kota Pekalongan haruslah segera belajar adaptasi dengan lingkungan barunya dan belajar mengurus dirinya sendiri.

Kedua, Toleransi, sikap ini diajarkan secara langsung dalam memahami antar teman satu dengan lainnya.

Ketiga, Teratur, dengan jadwal kegiatan yang telah di tentukan maka semua peserta didik tidak dapat berbuat sesuka hatinya, mulai dari bangun tidur sampai kembali tidur sudah terjadwal dengan baik.

Keempat, Pendamping, dengan adanya pendamping di asrama dapat membuat nyaman para peserta didik dalam mengontrol kegiatan selama 24 jam.

Kelima, Risiko terlambat sangat minim, hal ini karena boarding school menyatu dengan madrasah. Siswa yang ikut serta dalam boarding school akan lebih tepat waktu masuk ke sekolah formal di MAN 1 Kota Pekalongan.

Keenam, Makan teratur, pola makan peserta didik dapat teratur dan terjamin sesuai dengan waktu yang sudah dijadwalkan.

Ketujuh, Aman, tinggal di asrama akan merasa aman dibandingkan dengan kos atau tempat tinggal sekitar asrama yang tidak punya jadwal yang teratur.

Kedelapan, Fasilitas memadai, berbagai hal yang berkaitan dengan kegiatan ekstra atau sejenisnya, biasanya disediakan di asrama tersebut. Hal ini jelas menjadi poin penting, supaya siswa tetap nyaman di boarding school (Purnama, 2010, h. 63-65).

Dari beberapa manfaat $\mathrm{di}$ atas, kemandirian akan dirasakan oleh siswa yang ikut serta di boarding school.
Kemandirian merupakan kemampuan dalam mengerjakan sesuatu secara sendiri dengan penuh tanggung jawab. Sedangkan Desmita menyatakan bahwa kemandirian adalah kemampuan seseorang mengatur dan mengendalikan pikiran, perasaan, dan perbuatan secara bertanggung jawab serta berusaha semaksimal mungkin meminimalisir perasaan malu dan ragu-ragu pada diri sendiri (Desmita, 2010, h. 185).

Kemandirian pada siswa diperoleh secara bertahap seiring dengan perkembangan aspek-aspek kepribadian dalam diri mereka. Dimana siswa akan belajar bersikap mandiri dalam menghadapi berbagai situasi di lingkungan, sehingga anak pada akhirnya akan mampu berpikir dan bertindak sendiri. Seseorang yang mandiri adalah suatu suasana dimana seseorang mau dan mampu mewujudkan kehendak atau keinginan dirinya yang terlihat dalam tindakan atau perbuatan nyata guna menghasilkan sesuatu demi pemenuhan kebutuhan hidupnya dan sesamanya (Antonious, 2002, h. 145).

Untuk melihat kemandirian siswa di boarding school, setidaknya bisa dilihat dari beberapa bentuk kemandirian, diantaranya:

Pertama, Kemandirian emosi yaitu siswa yang ikut serta dalam boarding school akan dituntut belajar mengatur emosinal dirinya sendiri, mampu meregulasi dri, dan mampu memotivasinya dirinya sendiri. Hal ini dikarenakan, para siswa jauh dari orang tua, dan ketika yang biasanya merengek pada orang tuanya, kini mereka harus belajar mengendalikan dirinya sendiri secara emosional.

Kedua, Kemandirian ekonomi yaitu siswa juga harus mampu mengatur keuangan mereka selama di boarding school, baik untuk jajan, membeli buku, dan lain sebagainya.

Ketiga, Kemandirian intelektual yaitu kemampuan kognitif siswa juga 
perlu digunakan sebaik mungkin, karena tidak hanya untuk belajar dan menyelesaikan tugas di sekolah formal pagi atau di MAN 1 Kota Pekalongan. Melainkan juga, siswa dituntut untuk menghafal Al-Qur'an, dan kegiatan lainnya yang perlu menguras kinerja otak di kegiatan boarding school.

Keempat, Kemandirian sosial yaitu dengan adanya boarding school, siswa dituntut untuk cepat beradaptasi secara sosial dengan teman-temannya yang berbeda daerah, dialek bahasa, dan lainnya yang menjadi ciri khas dari tiap siswa (Desmita, 2010, h. 186).

\section{Pembiasaan sebagai Penguat dari Kemandirian}

Pembiasaan siswa yang rutin dilakukan di boarding school akan membuat siswa melakukannya dengan terbiasa. Pembiasaan ini tidak lain dan tidak bukan adalah untuk memberi penguat dari kemandirian yang sudah dimiliki siswa di boarding school. Maka dari itu menurut Pavlov perlu adanya penguat yang berupa pengulanganpengulangan, dengan tujuan menurut Skinner adalah untuk mempertahankan perilaku yang sudah baik dalam diri siswa (Sagala, 2003, h. 114). Hal inilah yang sebenarnya selalu diterapkan oleh kepala dan pengurus boarding school MAN 1 Kota Pekalongan.

Siswa dibiasakan dengan kegiatan yang sesuai dengan jadwal di boarding school. Memang awalnya, siswa akan merasa berat dengan rutinitas yang baru menurut para siswa. namun, lambat laun dengan berjalannya waktu, rutinitas dan pengulangan-pengulangan dari kegiatan yang ada di boarding school akan membuat siswa terbiasa dan ada rasa bersalah jika melanggar dari ketentuan yang sudah ada di boarding school.

\section{Hukuman sebagai Pengingat}

Bagi siswa yang melanggar atau tidak melakukan kegiatan yang semestinya yang sudah dijadwalkan, siswa akan mendapatkan hukuman sesuai dengan apa yang siswa langgar di boarding school. Peringatan, teguran, dan bahkan hukuman tidak lain adalah untuk mengarahkan perilaku siswa yang kurang baik untuk menjadi lebih baik dari sebelumnya. Maka pemberian hukuman merupakan unsur tambahan yang sifatnya penting dalam konsep perubahan perilaku siswa (Zulhammi, 2015, h. 22). Namun perlu diingat kembali, untuk pemberian hukuman kepada siswa harus bertahap sesuai dengan kesalahan atau pelanggaran yang dilakukan siswa. Pemberian hukuman juga harus bersifat mendidik, bukan malah membuat siswa akan semakin memberontak pada kebijakan yang sudah dibuat di boarding school.

Namun di sisi lain, menurut Skinner hukuman tidak menurunkan probabilitas dari siswa yang melakukan pelanggaran. Walaupun hukuman bisa menekan suatu respons selama diterapkan, namun hukuman tidak akan melemahkan kebiasaan. Skinner juga berpendapat bahwa hukuman dalam jangka waktu panjang tidak akan efektif, tampak bahwa hukuman hanya menekan perilaku, dan ketika ancaman dihilangkan, tingkat perilaku akan ke level semula (Sagala, 2003, h. 122). Maka dari itu, perlunya kesadaran diri dari dalam diri siswa untuk melakukan segala kegiatan yang ada di boarding school, sebagai kewajiban mereka dan membuat siswa semakin matang dan mandiri dalam mengurus dirinya sendiri.

\section{PENUTUP}

Boarding school di MAN 1 Kota Pekalongan bertujuan membentuk siswa yang mandiri, baik secara emosional, ekonomi, intelektual, dan sosial. Di boarding school MAN 1 Kota Pekalongan memiliki beberapa program unggulan yaitu program tahfidz, program bahasa (Arab dan Inggris) dan program kajian kitab klasik. Selain itu, pengasuh asrama juga memantau seluruh kegiatan siswa 
untuk selalu mentaati dan mengikuti segala kegiatan yang ada di boarding school MAN 1 Kota Pekalongan.

Bentuk kemandirian siswa di boarding school seperti mencuci pakaian, mencuci peralatan masak, membersihkan tempat tidur sekaligus kamarnya. Kemandirian siswa dibentuk karena pembiasaan dari seluruh kegiatan yang ada di boarding school dan pengulanganpengulangan sebagai penguat dari sikap mandiri yang sudah dimiliki siswa. Hukuman atau punishment akan diterima siswa jika melanggar aturan maupun tidak melakukan kegiatan yang sudah dijadwalkan. Namun yang tidak kalah penting adalah kesadaran diri dari siswa untuk selalu berusaha melakukan kegiatan dengan baik, dan akan memperkuat rasa mandiri siswa di boarding school MAN 1 Kota Pekalongan.[]

\section{DAFTAR RUJUKAN}

Afifudin. Metodologi Penelitian Kualitatif. Bandung: Pustaka Setia, 2012.

A'la, Abd. Pembaruan Pesantren. Yogyakarta: Pustaka Pesantren, 2006.

Antonious, Gea. Relasi dengan Diri Sendiri. Jakarta: PT Gramedia, 2002.

$\begin{array}{cr}\text { Badan Pusat Statistik. } & \text { "Indeks } \\ \text { Pembangunan Manusia } & \text { (IPM) } \\ \text { Indonesia pada tahun } & 2019\end{array}$ mencapai 71,92," 2020. Daring. Internet. 5 Mei 2020. . Available: https://www.bps.go.id/pressreleas e/2020/02/17/1670/indekspembangunan-manusia--ipm-indonesia-pada-tahun-2019mencapai-71-92.html.

Behaghel, Luc, Clément de Chaisemartin, dan Marc Gurgand. "Ready for Boarding? The Effects of a Boarding School for Disadvantaged Students." American Economic Journal: Applied Economics 9.1 (2017): 140-164.

Busyairi AS, M. "Education Unit Transformation for Maintain Its
Existence in Islamic Boarding School (Multi-Case Study on Tebuireng Islamic Boarding School, Gading Islamic Boarding School Malang, and Sidogiri Islamic Boarding School Pasuruan)." Journal of Education and Practice 8.5 (2017): 56-64.

Das, St Wardah Hanafie, Abdul Halik, dan Amaluddin. "Paradigm of Islamic Education in the Future: The Integration of Islamic Boarding School and Favorite School." Information Management and Business Review 8.4 (2016): 24-32.

Desmita. Psikologi Perkembangan Peserta Didik. Bandung: PT. Rosda Karya, 2010.

Evans-Campbell, Teresa dkk. "Indian Boarding School Experience, Substance Use, and Mental Health among Urban Two-Spirit American Indian/Alaska Natives." The American Journal of Drug and Alcohol Abuse 38.5 (2012): 421-427.

Fathonah, Dewi Yulia, Taty Hernawaty, dan Nita Fitria. "Respon Psikososial Siswa Asrama di Bina Siswa Sma Plus Cisarua Jawa Barat." Jurnal Pendidikan Keperawatan Indonesia 3.1 (2017): 69-77.

Haeruddin, Bahaking Rama, dan Wahyuddin Naro. "Implementasi Pendidikan Karakter di Pondok Pesantren An-Nurîyah Bonto Cini' Kabupaten Jeneponto Provinsi Sulawesi Selatan." Jurnal Pendidikan Agama Islam Al-Thariqah 4.1 (2019): 60-73.

Keller, Chad J., dan Chris Brown. "Conflictual Independence, Adult Attachment Orientation, and Career Indecision Among Asian American Students." Journal of Career Development 41.5 (2014): 426-444.

Mander, David J, Leanne Leaster, dan Donna Cross. "The social and emotional well-being and mental health implications for adolescents 
transitioning to secondary boarding school." Int J Child Adolesc Health 8.2 (2015): 131-140.

Martin, Andrew J. dkk. "Boarding School, Academic Motivation and Engagement, and Psychological Well-Being: A Large-Scale Investigation." American Educational Research Journal 51.5 (2014): 1007-1049.

Nasir, M. Ridlwan. Mencari Tipologi Format Pendidikan Ideal: Pondok Pesantren Di Tengah Arus Perubahan. Yogyakarta: Pustaka Pelajar, 2011.

Purnama, Dian. Cermat Memilih Sekolah Yang Tepat. Jakarta: Gagas Media, 2010.

Qomar, Mujamil. Dimensi Manajemen Pendidikan Islam. Bandung: Emir Cakrawala Islam, 2015.

Qomar, Mujamil. Pesantren dari Transformasi, Metodelogi Menuju Demokrasi Institusi. Bandung: Erlangga, 2008.

Rajab, Khairunnas. "Methodology of Islamic psychotheraphy in Islamic boarding school Suryalaya Tasik Malaya." Indonesian Journal of Islam and Muslim Societies 4.2 (2014): 257-289.

Sadulloh, Uyoh. Pedagogik (Ilmu Mendidik. Bandung: Alfabeta, 2010.

Sagala, Syaiful. Konsep Dan Makna Pembelajaran. Bandung: Alfabeta, 2003.

Sawaluddin. "Konsep Evaluasi Dalam Pembelajaran Pendidikan Islam." Jurnal Pendidikan Agama Islam AlThariqah 3.1 (2018): 39-52.

Schaverien, Joy. "Boarding School Syndrome: Broken Attachments a Hidden Trauma." British Journal of Psychotherapy 27.2 (2011): 138155.

Siregar, Eveline, dan Hartini Nara. Teori Belajar dan Pembelajaran. Bogor: Ghalia Indonesia, 2011.
Susanto, Tutut dkk. "School health promotion: A cross-sectional study on Clean and Healthy Living Program Behavior (CHLB) among Islamic Boarding Schools in Indonesia." International Journal of Nursing Sciences 3.3 (2016): 291298.

Susiyani, Andri Septilinda, dan Subiyantoro. "Manajemen Boarding School dan Relevansinya dengan Tujuan Pendidikan Islam di Muhammadiyah Boarding School (MBS) Yogyakarta." Jurnal Pendidikan Madrasah 2.2 (2017): 327-347.

Sutyawan, Sutyawan, dan Budi Setiawan. "Penyelenggaraan Makanan, Daya Terima Makanan, dan Tingkat Asupan Siswa Asrama Kelas Unggulan SMA 1 Pemali Bangka Belitung." Jurnal Gizi dan Pangan 8.3 (2013): 207-216.

Tafsir, A. Cakrawala Pemikiran Pendidikan Islam. Bandung: Mimbar Pustaka, 2004.

Usman, Nasir, Murniati Ar, dan Marzuki Marzuki. "The Influence of Leadership In Improving Personnel Performance At Traditional Islamic Boarding School (Dayah)." Jurnal Ilmiah Peuradeun 4.2 (2016): 205216.

Yin, Xue-Qin, et al. "The Promotive Effects of Peer Support And Active Coping on the Relationship Between Bullying Victimization And Depression Among Chinese Boarding Students." Psychiatry research 256 (2017): 59-65.

Zulhammi, Zulhammi. "Teori belajar behavioristik dan humanistik dalam perspektif pendidikan Islam." Darul 'Ilmi: Jurnal Ilmu Kependidikan dan Keislaman 3.1 (2015): 105-125. 